\title{
The choice of indicators for monitoring financial regulation of sustainable development of agricultural regions: the example of Ukraine
}

\author{
Leonid Tulush, Oksana Radchenko*, and Olena Hryshchenko \\ National Science Center «Institute of Agrarian Economics», Kyiv, Ukraine
}

\begin{abstract}
The influence of a group of indicators on the integral assessment of the state of agrarian regions for improving the financial mechanisms for regulating sustainable rural development has been investigated. The goal is to identify the relationship between the level of economic growth (growth in agricultural GDP, GVA per employee, income per community resident) and the amount of resources that are financed from the budgets. The empirical study was carried out on the basis of panel data formed for a sample of individual indicators of the rating of regional development of Ukraine for 2017-2019. The nature of the distribution of the studied variables was determined by calculating the correlation coefficients. Based on the results, a relationship was established between the indices: budget financing and gross production - 63\%; budget financing and integral production index $58 \%$; income of rural budgets and profit of agricultural production - 38\%. It is recommended to reduce direct agricultural subsidies, increase the allocation of funds for social development, and finance the most effective programs in order to ensure sustainable development of rural regions. To monitor the process of the effectiveness of financial regulation, it is proposed to use production, economic and social indicators in conjunction with the integral, which will become a more reliable basis for the distribution of budgetary allocations for agricultural and social development in Ukraine.
\end{abstract}

\section{Introduction}

Ukraine is traditionally an agrarian country, where agriculture accounted for $1 / 4$ of the GDP. In recent decades, this contribution has decreased to $10 \%$, but it is still a significant value against the level of developed countries, where it is not higher than $3 \%$. The industryspecific gross product of Ukraine created annually is about UAH 350 billion or US \$ 13 billion [1].

Having a significant impact on the economy, the agricultural industry is an integral part of rural areas. Taking into account the challenges of the time and taking into account the experience of the European Union, it became necessary to create a comprehensive strategy for the sustainable development of the agricultural and rural sectors in the regional context. In practice, these sectors are little interconnected, especially in terms of financing and there

\footnotetext{
* Corresponding author: oxanarad@ukr.net
} 
is a need for government regulation. Establishing such interdependence requires defining the essence and introducing an effective financial regulation mechanism, otherwise there is a real threat of excessive polarization and growth of disproportions within the regions and the country.

The issue of regional agricultural development and the measurement of its indicators and indicators is relevant for the whole world, since the Food and Agriculture Organization of the United Nations has chosen a common strategy for Sustainable Development [2].

At the national level, Mesel-Veselyak \& Grishchenko [3] determined that the integral indicator for regional development reveals three groups of indicators: assessment of the level of agricultural production (yield, productivity); assessment of the economic state of the agricultural sector (profitability, cost recovery); assessment of the social development of rural areas (demography, household cash income, unemployment rate; average monthly wages in the agricultural sector; consumption per person). Sokil et al. [4] provides a methodology for assessing and determining the integral indicator of sustainable development of agriculture on the basis of accounting and analytical indicators of three components of sustainable development (economic, environmental, social). Kozlovskyi et al. [5] believe that the lack of a generally accepted definition of the concept of "sustainable development of the agricultural sector" is caused by the lack of information to measure it. They offer a solution to the problem by drawing up an indicative plan for the development of the agrarian sector of the region in correlation with the concept of regional development. Chopin et al. [6] investigated that an assessment of agriculture on a regional scale is needed to better guide regional planning. A method based on a set of multiscale indicators has been developed to assess the contribution of agriculture to the sustainable development of regions.

International studies such as Morkunas et al. [7] are aimed at identifying and assessing the negative consequences of the introduction of a mechanism for financial support for direct payments under the Common Agricultural Policy for the sustainability of rural areas. It was found that high land prices, declining crop diversification, land degradation and farmers' financial indebtedness can be attributed to direct payments, and these effects have a significant negative impact on agricultural sustainability. Crescenz et al. [8] analyze the financial allocations for regional policy, rural development policy and agrarian policy of the European Union in order to assess their territorial coordination and synergy for territorial cohesion. Regression analysis is used to identify the link between funding and territorial disadvantage, showing that both coordination and compatibility with territorial cohesion have not always improved in response to major policy reforms, but are critically dependent on appropriate local allocation mechanisms.

Considering the achievements of the researchers, problematic issues remain: despite the decisions of the Government of Ukraine adopted in recent years to stimulate the development of rural areas, today the effectiveness of most public policy measures in this area remains low.

\section{Research methodology}

To assess the nature and features of the impact of financial regulation on the sustainable development of the agricultural sector and rural areas, general and special methodological approaches are used: determining the degree of development of a rural region involves the use of special indicators, the main of which is the sectoral agrarian gross product (GDP), its dynamics during research period (per employee); identification of the nature of the dependence of agricultural GDP, production, financial results and social factors and other macro indicators; identifying the nature of the dependence of changes in agricultural GDP and the distribution of financial resources that the state controls (lending, the Regional Development Fund, support for agricultural production from local budgets). 
The indicators of payments from the Regional Development Fund (SFRD) were selected as the basis for assessing the regional financing rating as a comprehensive assessment; lending to agricultural enterprises with government subsidies for loan repayment; payments from local budgets to support agricultural production.

The calculations took into account the Methodology for monitoring and the effectiveness of the implementation of the state regional policy [9] and Information on monitoring the development of rural areas [10].

Regional rating assessments of agricultural development are calculated according to the following algorithm (Mesel-Veselyak \& Grishchenko, [3]): the ratio (indices) of each indicator of the regions to the average for Ukraine with differentiation of indicators, the increase of which has a positive value (stimulants), and negative (destimulators) value; the integral rating is calculated as the arithmetic mean of the sum of the rating indices of a particular region for all groups of indicators according to the formula:

$$
I_{0}=\left(I_{n}+I_{e}+I_{c}\right) / 3
$$

where Io is the general index for three groups of indicators; In - production index; Ie economic condition index; Ic - social.

The general rating assessment [9] is carried out by comparing the deviation of the values of indicators for each specific region from their best values for the regions for the corresponding (reporting) period and the corresponding ranking of regions.

The rating assessment is carried out on the basis of calculating the relative deviations of the indicators of each region of the maximum and minimum values of such indicators of other regions according to the formula:

$$
R_{j}=\sum_{i=1}^{n} \frac{x_{\max i}-x_{i j}}{x_{\max i}-x_{\min i}}+\sum_{i=1}^{n} \frac{x_{i j}-x_{\min i}}{x_{\max i}-x_{\min i}}
$$

where $\mathrm{Rj}$ is the sum of the ratings of a particular region for each of the indicators characterizing a particular area of activity; $x i j$ is the value of the $i$-th indicator of the $j$-th region; $x \max \mathrm{i}$ - maximum value of the $\mathrm{i}$-th indicator; $x \min \mathrm{i}$ - the minimum value of the $\mathrm{i}$-th indicator.

The definition of the arithmetic mean of the sum of the ratings of a particular region for all indicators of the annual assessment, characterizing a particular area of activity, is carried out according to the formula:

$$
R_{c p j}=\frac{R_{j}}{n}
$$

where Rcpj is the arithmetic mean of the sum of the ratings of a particular region for all indicators of a particular direction; $\mathrm{n}$ is the number of indicators for which the calculation was made in certain areas.

Based on the results of the calculations, the integral rating is determined as the arithmetic mean of the sum of rating assessments of a particular region in all areas according to the formula:

$$
I_{j}=\frac{\sum_{i=1}^{m} R_{c p i}}{m}
$$

where $\mathrm{Ij}$ is the arithmetic mean of the sum of the ratings of a particular region in all directions; $\mathrm{m}$ - the number of directions in which the calculation was made. 


\section{Results of the research}

\subsection{Analysis of the production group of indicators of agrarian and rural development}

In general, the hypothesis of the study is formulated as follows: there is a high statistical relationship between the indicator of financial regulation of the economy and indicators of sustainable agricultural and rural development of production.

To test the hypothesis, we will conduct an econometric analysis of the influence of factors on the resulting indicators, construct an econometric equation of linear multiple regression. We use three criteria that characterize the main trends in the state of agrarian and rural development: 1) production index by indicators: gross output per hectare, output per person and gross added value of the industry per hectare; 2) the index of economic condition: profit per hectare, per 1 person, per 1 hryvnia of expenses; 3) social index: employment, unemployment, wages per employee, income per person. As a result, we get a general index for three groups of indicators and a rating by the region behind it (Table 1).

The period of three years used by us (2017-2019) is a sufficient lag to determine mediumterm trends, and the geometric mean serves as the basic average for studying time series. Used data from the official website of the State Statistics of Ukraine [11].

Table 1. Rating of regions of Ukraine according to the integral assessment of agricultural production.

\begin{tabular}{|c|l|c|c|c|c|c|}
\hline \multirow{2}{*}{$№$} & \multirow{2}{*}{ Regions } & \multicolumn{4}{|c|}{ Index } & \multirow{2}{*}{ Rating } \\
\cline { 3 - 6 } & & Produc & Effic & Social & General & \multirow{2}{*}{} \\
\cline { 3 - 6 } & & In & Ie & Ic & Io & \\
\hline 1 & Vinnitsa & 1,35 & 0,35 & 1,08 & 0,93 & 6 \\
\hline 2 & Volyn & 0,73 & 0,24 & 1,04 & 0,67 & 18 \\
\hline 3 & Dnipro & 1,27 & 0,39 & 0,95 & 0,87 & 11 \\
\hline 4 & Donetsk & 0,81 & 0,25 & 1,13 & 0,73 & 17 \\
\hline 5 & Zhytomyr & 1,06 & 0,27 & 1,05 & 0,80 & 14 \\
\hline 6 & Transcarpat & 0,73 & 0,22 & 1,00 & 0,65 & 21 \\
\hline 7 & Zaporizhz & 1,03 & 0,47 & 0,98 & 0,83 & 13 \\
\hline 8 & Iv-Frankivsk & 0,79 & 0,10 & 1,08 & 0,65 & 20 \\
\hline 9 & Kiev & 1,35 & 0,47 & 0,94 & 0,92 & 7 \\
\hline 10 & Kirovograd & 1,55 & 0,46 & 1,06 & 1,02 & 1 \\
\hline 11 & Luhansk & 0,71 & 0,30 & 1,23 & 0,75 & 16 \\
\hline 12 & Lviv & 0,74 & 0,18 & 1,00 & 0,64 & 23 \\
\hline 13 & Nikolaev & 1,24 & 0,44 & 1,00 & 0,89 & 9 \\
\hline 14 & Odessa & 0,78 & 0,39 & 0,83 & 0,66 & 19 \\
\hline 15 & Poltava & 1,45 & 0,37 & 1,10 & 0,97 & 3 \\
\hline 16 & Rivne & 0,76 & 0,21 & 0,98 & 0,65 & 22 \\
\hline 17 & Sumy & 1,43 & 0,45 & 1,01 & 0,96 & 4 \\
\hline 18 & Ternopil & 0,89 & 0,33 & 1,11 & 0,78 & 15 \\
\hline 19 & Kharkiv & 1,31 & 0,35 & 0,87 & 0,84 & 12 \\
\hline 20 & Kherson & 1,20 & 0,43 & 1,02 & 0,88 & 10 \\
\hline 21 & Khmelnitsk & 1,29 & 0,51 & 0,98 & 0,93 & 5 \\
\hline 22 & Cherkasy & 1,29 & 0,43 & 1,05 & 0,92 & 8 \\
\hline 23 & Chernivtsi & 0,81 & $-0,05$ & 0,86 & 0,54 & 24 \\
\hline 24 & Chernihiv & 1,40 & 0,43 & 1,10 & 0,98 & 2 \\
\hline
\end{tabular}

Statistical analysis found that multiple $\mathrm{R}$, which characterizes the tightness of the relationship between the analyzed factors, was 0.6576, that is, the characteristic of the relationship is moderate, but significant. At the same time, the R2 indicator is low - 0.4325 , as well as the adapted R-square $2-0.4067$, with a standard error (deviation of all sample 
means) 0.5268 . The regression analysis of the integral assessment of agricultural production is given in table. 2 .

Table 2. Regression analysis of the integral assessment of agricultural production.

\begin{tabular}{|l|l|l|l|l|l|l|}
\hline & Coef.. & Standard error & t-statistics & P-Value & Lower 95\% & Upper 95\% \\
\hline Y & $\begin{array}{l}3,051 \\
4\end{array}$ & 1,1474 & 2,659 & 0,015 & 0,6578 & 5,4450 \\
\hline In & $\begin{array}{l}0,032 \\
2\end{array}$ & 0,4809 & 0,0669 & 0,9472 & $-0,971$ & 1,0355 \\
\hline Ie & $-3,914$ & 1,0218 & $-3,830$ & 0,0010 & $-6,045$ & $-1,782$ \\
\hline Ic & $-0,462$ & 1,0581 & $-0,437$ & 0,6667 & $-2,669$ & 1,744 \\
\hline
\end{tabular}

\subsubsection{Analysis of the financial group of indicators of agrarian and rural development}

Another group of resulting indicators relates to financing of agricultural, rural and regional development. These are the following indicators: 1) the index of payments from the Regional Development Fund (SFRD) per 1 hectare of the IFR territory; 2) index of lending to agricultural enterprises with state subsidies for repayment of loans, per 1 ha of land area of enterprises Ikr; 3) index of payments from local budgets to support agricultural production Imb. As a result, we obtain a general index of financing Iph for three groups of indicators (Table 3) for a comparable period.

Table 3. Rating of regions of Ukraine according to the integral assessment of financial support.

\begin{tabular}{|c|c|c|c|c|c|}
\hline \multirow{2}{*}{ Regions } & \multicolumn{4}{|c|}{ Index } & \multirow{2}{*}{ Rating } \\
\cline { 2 - 5 } & SFRD & Soft loans & Local budget & General & \multirow{2}{*}{} \\
\cline { 2 - 4 } & Ifr & Ikr & Imb & Iph & \\
\hline Vinnitsa & 1,01 & 0,51 & 2,64 & 1,39 & 9 \\
\hline Volyn & 1,23 & 1,71 & 4,97 & 2,64 & 2 \\
\hline Dnipro & 1,51 & 1,05 & 0,53 & 1,03 & 14 \\
\hline Donetsk & 3,24 & 0,11 & 1,49 & 1,61 & 7 \\
\hline Zhytomyr & 0,98 & 0,75 & 1,10 & 0,95 & 15 \\
\hline Transcarpat & 2,35 & 1,38 & 2,04 & 1,92 & 4 \\
\hline Zaporizhz & 0,94 & 0,92 & 0,66 & 0,84 & 17 \\
\hline Iv-Frankivsk & 2,34 & 1,22 & 1,77 & 1,77 & 6 \\
\hline Kiev & 0,92 & 1,13 & 1,23 & 1,10 & 12 \\
\hline Kirovograd & 0,58 & 0,86 & 1,27 & 0,90 & 16 \\
\hline Luhansk & 1,88 & 0,17 & 0,04 & 0,70 & 21 \\
\hline Lviv & 1,73 & 0,37 & 4,30 & 2,13 & 3 \\
\hline Nikolaev & 0,68 & 0,67 & 0,38 & 0,58 & 24 \\
\hline Odessa & 1,07 & 0,30 & 0,74 & 0,70 & 22 \\
\hline Poltava & 0,73 & 1,74 & 0,79 & 1,09 & 13 \\
\hline Rivne & 1,39 & 0,75 & 1,92 & 1,35 & 10 \\
\hline Sumy & 0,91 & 0,51 & 0,34 & 0,58 & 23 \\
\hline Ternopil & 1,81 & 2,90 & 0,86 & 1,86 & 5 \\
\hline Kharkiv & 1,23 & 0,98 & 0,00 & 0,74 & 20 \\
\hline Kherson & 0,85 & 0,40 & 0,99 & 0,75 & 19 \\
\hline Khmelnitsk & 1,43 & 1,85 & 0,70 & 1,33 & 11 \\
\hline Cherkasy & 0,86 & 3,36 & 0,23 & 1,48 & 8 \\
\hline Chernivtsi & 2,55 & 4,98 & 2,33 & 3,29 & 1 \\
\hline Chernihiv & 0,64 & 0,39 & 1,43 & 0,82 & 18 \\
\hline & & & & & \\
\hline & & & & \\
\hline
\end{tabular}


For this sample of factors, the analysis found that the multiple R, which characterizes the tightness of the relationship between the analyzed factors, was 0.7716 , the characteristic of the relationship is significant. The R2 index is 0.5953 , the standard error is 0.4665 .

The analysis of the correlation coefficients between the integral indicator of financing and production factors of the first correlation-regression model showed that the correlation dependence for Iph is observed for all production factors as a de-stimulating one: Iw ($0.5361)$, Ie (-0.7689), Ic $(-0,1017)$ (Table 4).

Table 4. Correlation matrix of the relationship between the integral indicator of financing and the factors of the production correlation-regression model.

\begin{tabular}{|c|c|c|c|c|}
\hline & $\mathrm{I}_{\phi}$ & $\mathrm{I}_{\mathrm{B}}$ & $\mathrm{I}_{\mathrm{e}}$ & $\mathrm{I}_{\mathrm{c}}$ \\
\hline $\mathrm{I}_{\phi}$ & 1,0000 & $-0,5361$ & $-0,7689$ & $-0,1017$ \\
\hline $\mathrm{I}_{\mathrm{B}}$ & $-0,5361$ & 1,0000 & 0,7094 & $-0,0059$ \\
\hline $\mathrm{I}_{\mathrm{e}}$ & $-0,7689$ & 0,7094 & 1,0000 & 0,0507 \\
\hline $\mathrm{I}_{\mathrm{c}}$ & $-0,1017$ & $-0,0059$ & 0,0507 & 1,0000 \\
\hline
\end{tabular}

To confirm the direction and closeness of the relationship, we construct a correlation field between the indicators of the financing index (Iph) and the production index (Ic) (Fig. 1).

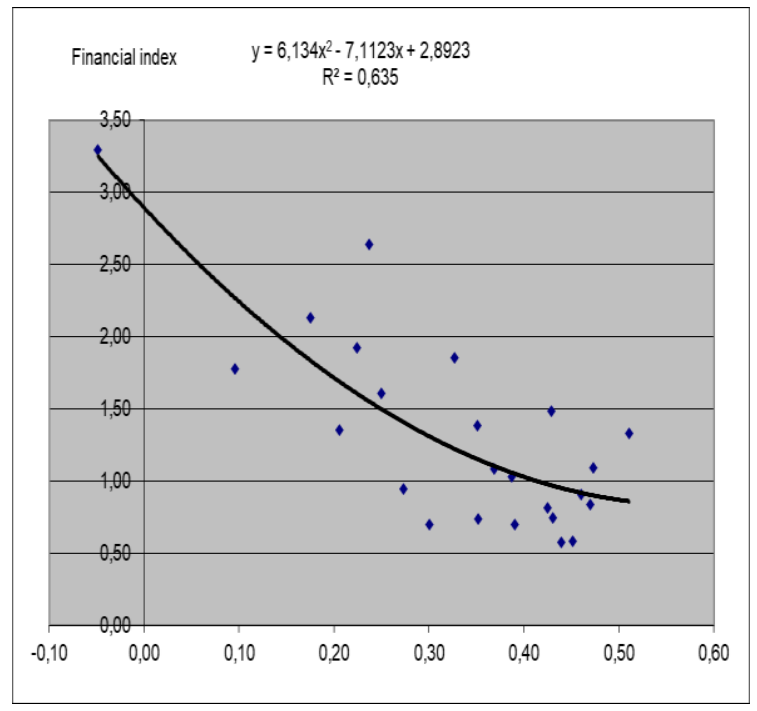

Fig. 1. Correlation dependences between the financing index $\left(I_{p h}\right)$ and the production index $\left(I_{v}\right)$.

The correlation dependences between the financing index (Iph) and the integral production index (Ic) are shown in Fig. 2. 


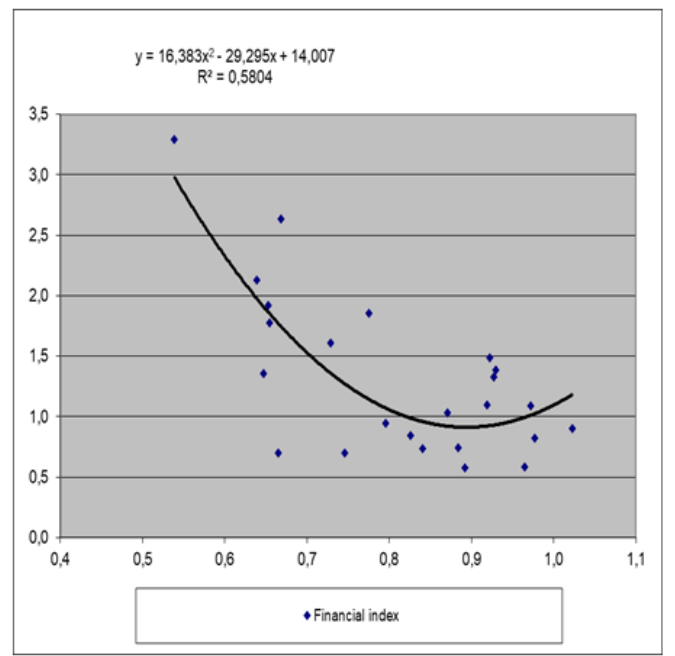

Fig. 2. Correlation dependences between the financing index (Iph) and the integral production index (I3).

\subsubsection{Analysis of a group of indicators of the development of territorial communities}

In addition to the factors of centralized budget financing and support for agricultural production, it is important to take into account the financial capacity of local budgets. According to the regional state administrations [12], thanks to the decentralization reform and the introduction of new tools to support the development of territories in most of the united territorial communities (UTGs), there is an increase in the main indicators characterizing the economic and financial efficiency of their development. The assessment is carried out on the basis of available official statistics and information from central and local executive authorities [13; 14], for 62 indicators characterizing the situation in 12 areas in different areas of socio-economic development of regions, the place of each region in a separate area and a generalizing rating place in all areas of assessment were determined.

Conducting horizontal alignment according to tax capacity and calculating the amount of subsidies is carried out according to the following parameters: population size; personal income tax receipts for the last reporting budget period; the tax capacity index of the corresponding budget. The basic subsidies are received by poor local budgets (with the level of income tax on personal income per person below 0.9 of the average for Ukraine $(80 \%$ of the amount required to the level of 0.9 ) to increase their level of financial security.

Reverse subsidies are used in the budgets of OTGs, where this figure is higher than the 1.1 average in Ukraine (50\% of the excess of the 1.1 tax capacity index is transferred to the state budget). Equalization is not carried out if in the local budget the level of income tax on personal income per inhabitant ranges from 0.9 to 1.1. This approach stimulates local governments to expand the base and attract additional financial revenues, contributes to an increase in the income of the general fund of the OTG budgets. The rating of Ukrainian OTG by financial criteria for 2019 is given in table. 5 . 
Table 5. Rating of the united territorial communities of Ukraine by financial criteria.

\begin{tabular}{|c|c|c|c|}
\hline Regions & number communities & income per person & Rating \\
\hline Vinnitsa & 37 & 3206 & 13 \\
\hline Volyn & 50 & 2588 & 11 \\
\hline Dnipro & 62 & 4402 & 19 \\
\hline Donetsk & 10 & 5103 & 15 \\
\hline Zhytomyr & 53 & 3135 & 8 \\
\hline Transcarpat & 6 & 3367 & 10 \\
\hline Zaporizhz & 44 & 3097 & 12 \\
\hline Iv-Frankivsk & 30 & 1648 & 3 \\
\hline Kiev & 16 & 4600 & 20 \\
\hline Kirovograd & 20 & 4569 & 14 \\
\hline Luhansk & 9 & 2770 & 6 \\
\hline Lviv & 40 & 2525 & 5 \\
\hline Nikolaev & 29 & 3543 & 21 \\
\hline Odessa & 28 & 3562 & 22 \\
\hline Poltava & 45 & 4988 & 23 \\
\hline Rivne & 32 & 2316 & 2 \\
\hline Sumy & 33 & 3617 & 9 \\
\hline Ternopil & 49 & 2239 & 1 \\
\hline Kharkiv & 17 & 4497 & 24 \\
\hline Kherson & 28 & 2742 & 17 \\
\hline Khmelnitsk & 45 & 2750 & 18 \\
\hline Cherkasy & 54 & 1365 & 4 \\
\hline Chernivtsi & 33 & 1714 & 7 \\
\hline Chernihiv & 39 & 3302 & 16 \\
\hline
\end{tabular}

The indicator "Financial self-sufficiency" includes indicators characterizing: the dynamics of growth of local budget revenues, the volume of capital expenditures per capita and repayment of the tax debt. In fig. 3 shows the correlation analysis of the dependence of the incomes of the OTG per 1 person. on the number of communities in the region.

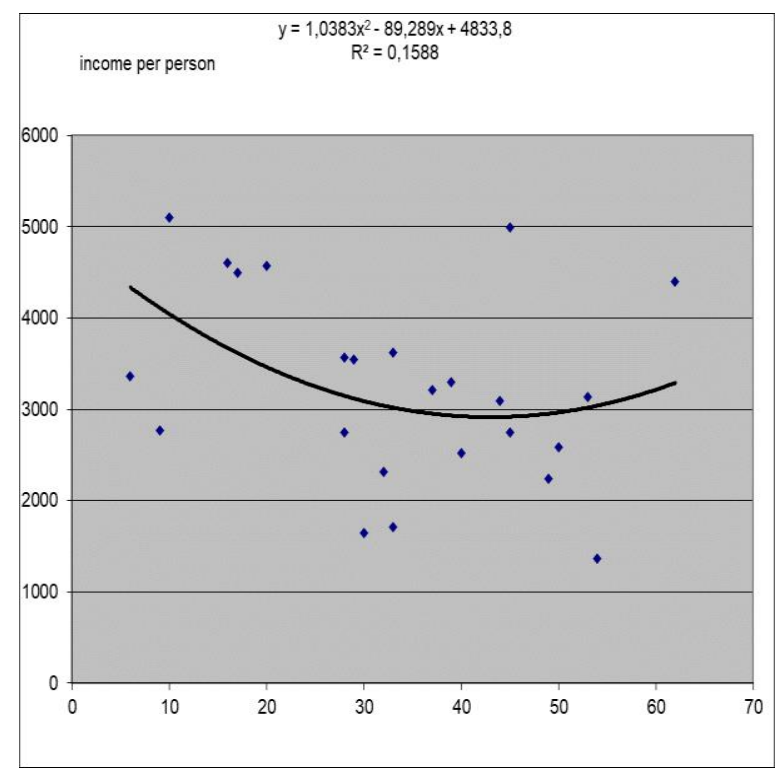

Fig. 3. Dependence of incomes of OTG per 1 person on the number of communities in the region. 
It was found that the relationship is insignificant, only $16 \%$. Thus, the number of communities is not conducive to an automatic increase in income; complex institutional measures are needed. Additional financial resources received by local budgets in recent years have made it possible to increase the volume of capital expenditures per capita in all regions, and on average in Ukraine per capita this indicator amounted to UAH 2.0 thousand in 20182019.

The analysis of the correlation dependence of the incomes of the OTG per 1 inhabitant on the integral index of agricultural production Iв is shown in Fig. 4.

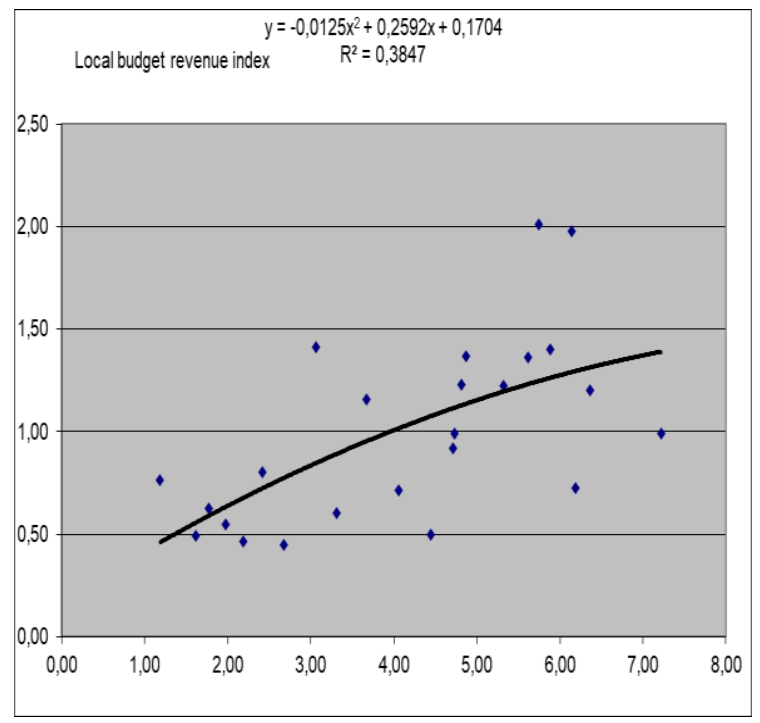

Fig. 4. Dependence of incomes of OTG per 1 person. from agricultural production Iv

The analyzed dependence is at the level of $38 \%$. This indicates an average relationship between these indicators. It could be higher, since many peasant farms are engaged in commodity production, but due to their exclusion from the tax field, local budgets receive less revenue from taxes.

\section{Discussion of results}

Calculations confirm the impact of state financial regulation on sustainable agricultural and rural development of territories. Our econometric analysis on the selection of indicators that have the most significant effect on the efficiency of the allocation of funds proves the hypothesis of the existence of a statistical relationship between state financial support and indicators of sustainable development of regions.

However, despite the multiple data sets designated for monitoring in the Methodological Recommendations [13], not all of them are equally useful for determining the criterion for allocating budget funds for the development of regions. Therefore, there is a need to abolish some indicators, while others, on the contrary, to expand.

Given the limited financial resources that the Government of Ukraine can direct to the development of territories, it is necessary to prioritize the allocation of resources and focus them on effective measures that can provide high results in the shortest possible time and carry out a long-term and comprehensive impact on the development of regions.

The Strategy, developed in the pre-crisis period, contains a list of many performance indicators, based on the analysis of the main trends in the socio-economic development of regions over the past 20 years and problems. Objective 3 "Effective public administration in 
the field of regional development" has been defined, which has 5 points of the structure and by 2020 some results have already been obtained [12] (tab. 6).

Table 6. Components of public administration Regional development strategies (Goal 3).

\begin{tabular}{|c|c|}
\hline Structure of Goal 3 & Status of implementation \\
\hline $\begin{array}{c}\text { 1.Decentralization of power, } \\
\text { reform of local government }\end{array}$ & $\begin{array}{c}\text { Measures are being taken to further introduce decentralization } \\
\text { processes, as of 19.03.2020 1,049 communities were formed }\end{array}$ \\
\hline $\begin{array}{c}\text { 2.Improving the system of } \\
\text { strategic planning for regional } \\
\text { development }\end{array}$ & $\begin{array}{c}\text { The new model of financial support contributed to an } \\
\text { increase in the revenue base of local budgets, revenues } \\
\text { increased 4 times to UAH 275 billion in 2019 against 2018 }\end{array}$ \\
\hline $\begin{array}{c}\text { 3.Improving the quality of } \\
\text { public administration of } \\
\text { regional development }\end{array}$ & $\begin{array}{c}\text { The introduction of tax preferences by the government, a } \\
\text { land market, additional budgetary support motivated the } \\
\text { unification of communities }\end{array}$ \\
\hline $\begin{array}{c}\text { 4. Strengthening cross-sectoral } \\
\text { coordination of government } \\
\text { policy }\end{array}$ & $\begin{array}{c}\text { Modern methods and means of cooperation are used, 1285 } \\
\text { communities signed 566 cooperation agreements in 2019 }\end{array}$ \\
\hline $\begin{array}{c}\text { 5.Institutional support of } \\
\text { regional development }\end{array}$ & $\begin{array}{c}\text { Formation of regional development agencies as a factor in } \\
\text { ensuring sustainable development and creating conditions for } \\
\text { enhancing investment }\end{array}$ \\
\hline
\end{tabular}

As a result of the national and global crises, a need arose to reduce the list of priorities for regional development in order to concentrate financial resources on the main tasks that have a systemic and long-term impact on the development of regions and the national economy as a whole.

To substantiate this conclusion, we have constructed a diagram of the optimal distribution of funds to support agricultural production from local budgets according to the integral index of production (Ih) (Fig. 5). At the same time, the blue lines are the actual distribution, the red lines are the leveled distribution of funds to support agricultural production from local budgets according to the integral production index.

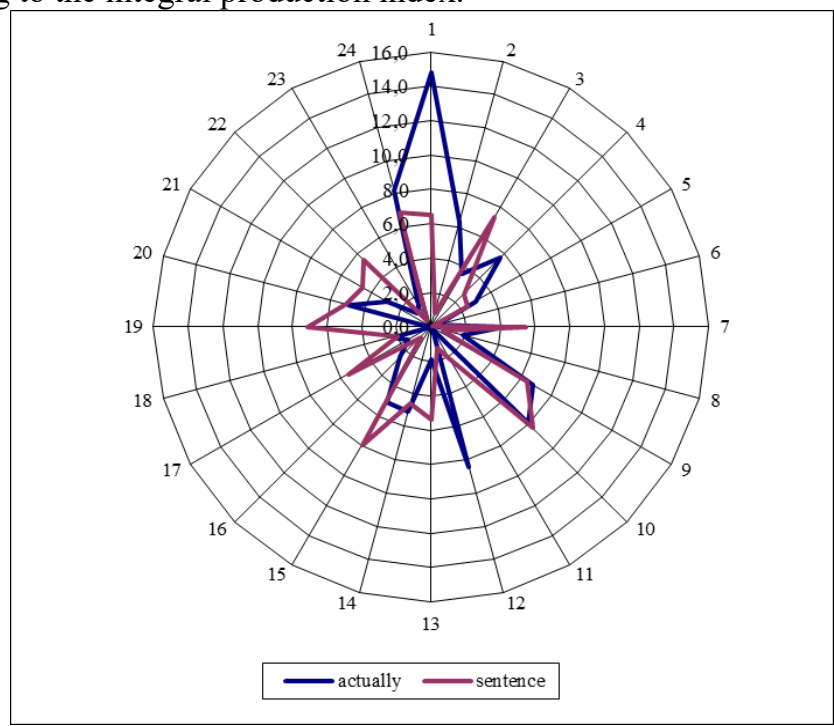

Fig. 5. Optimal distribution of funds to support agricultural production from local budgets according to the integral index of production (Iz).

The data indicate that some regions receive more funds from the state budget than their contribution to the structure of the agricultural GDP, which, in theory, was the guarantor of fair distribution. Such imbalances are eliminated precisely by a well-thought-out and 
effective policy of financial regulation, which contributes to the sustainable development of rural regions.

We also investigated the possibility of equalizing the OTG rating in terms of local budget revenues according to the criterion of integral ratings of production If and financing If (Fig. 6). At the same time, the blue lines are the actual rating, the red lines are the aligned rating of incomes of local budgets of OTG according to the integral ratings of production If and financing If.

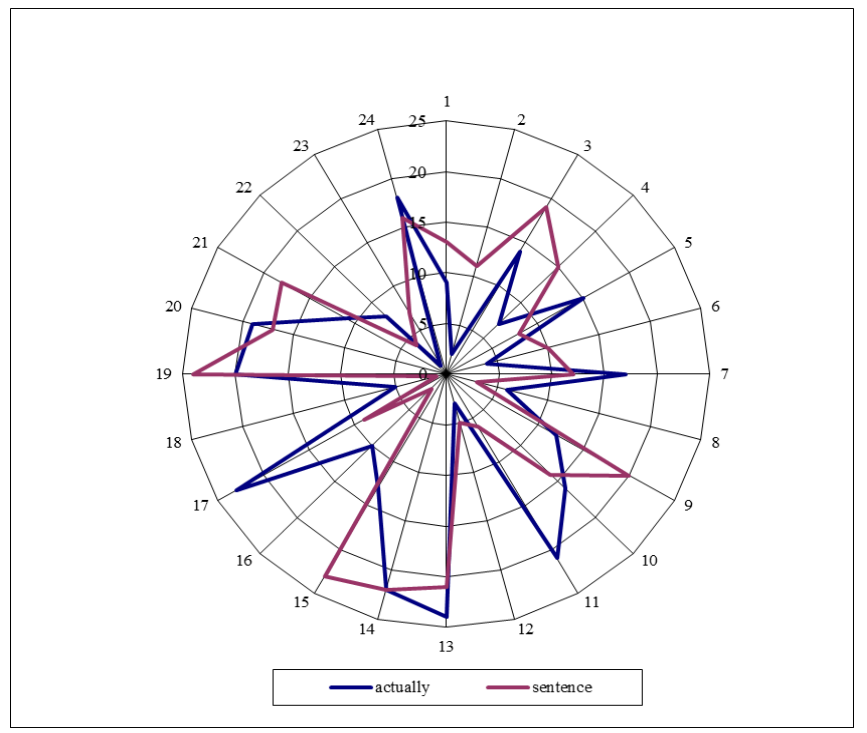

Fig. 6. Alignment of the rating of incomes of local budgets of OTG according to the integral ratings of production Iz and financing If.

In part, these conclusions were used to formulate the Strategy for Rural Development for the period up to 2030, developed by scientists of the NSC "Institute of Agrarian Economics" [15].

\section{Conclusions}

The confirmation of the influence of financial regulation on sustainable development was obtained, which confirmed the hypothesis put forward about the existence of a certain natural relationship between the dynamics of the development of the agricultural sector and state support, taking into account production, economic and social factors.

The indices and ratings of the development of the agrarian regions of Ukraine were determined according to the main indicators for 2017-2019. The analysis of the nature of the dependence of agricultural GDP, lending, payments from the Territorial Development Fund and other main macroeconomic indicators is carried out. The nature of the dependence of changes in the output of agricultural products, financial performance indicators and social factors is revealed, and the average degree of dependence between them is established. The existence of a significant statistical relationship (a significant correlation coefficient and a statically significant correlation-regression model) between the financing indicator and indicators of agricultural and rural development has been proved. The study makes it possible to substantiate the necessity and expediency of taking into account the influence of groups of factors on the formation of a package of government programs to support regions. 
The rating assessment of sustainable development of rural regions by groups of indicators characterizing the patterns of distribution of financial resources is given, which will allow regions with a low rating to focus on the most important measures to level the estimated indicators.

In order to ensure sustainable development of rural regions, it is recommended to reduce direct agricultural subsidies, increase the allocation of funds for social development, and finance the most effective programs. To monitor the process of the effectiveness of financial regulation, it is proposed to use production, economic and social indicators in conjunction with the integral, which will become a more reliable basis for the distribution of budgetary allocations for agricultural and social development in Ukraine.

Further continuation of the study of the topic of choosing indicators for monitoring and assessing agricultural and rural development for Ukraine should be based on indicative planning [4] (Strategic Directions, 2020). according to the formed principles of the strategy for sustainable development of rural areas in the following areas: natural resource potential, settlement aspects, sustainable development management, diversification of the rural economy, employment, improving the well-being and social protection of the rural population; development of entrepreneurship and service cooperation, innovation support, improvement of housing conditions, transport infrastructure, general education services, medical assistance, agritourism and recreational potential, environmental safety, financial and investment support, credit support, information and consulting activities for the development of the village and the social sphere.

\section{References}

1. Sait Ministerstva finansiv Ukrainy. The website of the Ministry of Finance of Ukraine. https://index.minfin.com.ua/economy/gdp/2019/

2. Food and Agriculture Organization of the United Nations. Sustainable Development Goals (2018). http://www.fao.org/sustainable-development-goals/overview/en

3. V.Ia. Mesel-Veseliak, E.Iu. Hryshchenko, Ekonomika APK, 11, 11 (2017)

4. O. Sokil, V. Zhuk, L. Vasa, Integral assessment of the sustainable development of agriculture in Ukraine. Economic annals-XXI, 170 (2018)

5. S. Kozlovskyi, V. Baidala, O. Tkachuk, T. Kozyrska, Montenegrin Journal of Economics 14(4), 175 (2018)

6. P. Chopin, J.M. Blazy, L. Guindé, R. Tournebize, T. Doré, Land Use Policy, 62, 132 (2017)

7. M. Morkunas, P. Labukas, Agriculture 10(6), 228 (2020).

8. R. Crescenzi, De Filippis, F. Pierangeli, Regional Studies 49(4), 681 (2015)

9. On the coordination of materials of the Procedure and Methods for monitoring and evaluating the effectiveness of the implementation of the state regional policy. Resolution of the Cabinet of Ministers of Ukraine 21.10.2015 № 856 . https://zakon.rada.gov.ua/laws/show/856-2015-\%D0\%BF\#Text

10. Information about the monitoring of the development of rural areas (mountain, OTG). https://www.minregion.gov.ua/napryamki-diyalnosti/derzhavna-rehional-napolityka/monitorynh/informatsiya-pro-monitoring-rozvitku-silskih-teritoriy-girskihotg/

11. State Statistics Service of Ukraine. Agriculture of Ukraine in 2000-2017: statistical collection. http://www.ukrstat.gov.ua/ 
12. Report on the results of monitoring and evaluating the effectiveness of the implementation of the state regional policy in 2019. https://www.minregion.gov.ua/wpcontent/uploads/2020/05/analiz-soczialno-ekonomichnogo-rozvytku-regioniv-za-2019rik.pdf

13. About the consolidation of methodical recommendations and the formulation and implementation of forecast and program documents of the social and economic development of the united territorial community 30.03.2016 № 75 . https://zakon.rada.gov.ua/rada/show/v0075858-16\#Text

14. Indicators Execution of OTG budgets. https://decentralization.gov.ua/news/11926

15. Yu.O. Lupenko, M.I. Malik, O.H. Bulavka ta in. Strategic directions for sustainable development of rural areas for the period up to 2030, Kyiv: NNTs IAE (2020) 